say, will bear in mind those old old biblical maxims : "Do unto others as you would have them do unto you," and "with what measure ye mete it shall be measured to you again."

\title{
Proposed Optical Practitioners Bill
}

According to the Pharmaceutical Journal and Pharmacist, January 23,1926 , a draft of a proposed Bill bearing this title has been sent to that journal. It aims at securing the registration of optical practitioners and regulating the practice of sight testing and optical dispensing. The details as given by the journal are as follows :

"The Bill defines optometry as sight testing or the examination of the human eye for the purpose of ascertaining any departure from the normal state of vision, measuring its functional powers, and adapting mechanical means for the aid thereof, and the expression includes the giving of any treatment, advice, or attendance on or to any person as preparatory to, or for the purpose of, or in connection with the processes aforesaid, and any treatment, advice, or attendance usually given by optometrists or refractionists. A dispensing optician is defined as a person who dispenses optical prescriptions and appliances.

"According to the Bill any person over the age of twenty-one shall be entitled to be registered as an optometrist if $(a)$ he satisfies the Board that he holds a recognized certificate; $(b)$ if he satisfies the Board that he has been engaged in the practice of optometry in Great Britain for five years before the passing of the Act and passes a practical examination in optometry deemed by the Board sufficiently comprehensive to safeguard the public; application for registration under this rule must be made within six months after the passing of the Act; or $(c)$ having completed the prescribed training, has passed the prescribed examination.

"Any registered optometrist shall be entitled to practise optometry, to dispense optical prescriptions and appliances, and to give certificates relating to visual acuity or visual defects, which shall be recognized as valid by any local or central authority or Government department in any part of Great Britain.

"Any person over the age of twenty-one may be registered as a dispensing optician if he has been engaged in the business of dispensing optical prescriptions and appliances for five years before the passing of the Act (application to be made within six months) or has completed the prescribed training and has passed the prescribed examination. This registration will not entitle the holder to practise optometry."

The Bill sets out penalties of unregistered practice. "For unregistered practice as an optometrist the maximum penalty is to 
be $£ 100$, and as dispensing optician the maximum fine is $£ 20$. No person, unless he is registered, may sell or offer for sale, or exhibit samples of, or accept orders or commissions for, or carry stocks of spectacles or eyeglasses. The maximum fine for this offence is to be £10. Bona fide wholesalers, however, are allowed to carry out transactions in the ordinary way of wholesale dealing. Under certain conditions a body corporate may carry on the business of optometry, if it carries on no other business than optometry or some business ancillary to the business of optometry, and if a majority of the directors and all the operating staff are registered optometrists.

"Nothing in the Act is to prevent the carrying on of the business or practice of optometry, or the clinical training of students in optometry in any hospital of any description or any optometric school approved by the Board.

"The Bill proposes a registration fee of not more than $£ 5$, and an annual fee of not more than $£ 3$ for an optometrist, and a registration fee of not more than $£ 3$ and an annual fee of not more than $£ 2$ for a dispensing optician.

"The first registrar is to be appointed by the Minister of Health and thereafter by the Board. Until the Board has compiled the register there is to be a temporary register, approved by the Minister of Health. The first Board is to consist of twenty-two persons as follows: Two appointed by the General Medical Council ; five persons, one to be appointed by each of the senates of the Universities of Edinburgh, Bristol, London, Manchester, and Sheffield; twelve to be elected by and from the persons on the temporary register ; and three appointed by the Minister of Health, of whom one is to be a dispensing optician, and the remaining two optometrists, but not included in the temporary register. This Board is to hold office for not more than three years, and the constitution of all subsequent Boards is two persorls appointed by the General Medical Council, the five university representatives, and fifteen persons elected from the register.

The Bill provides for the removal from the register or for suspension from practice of a practitioner who has been found guilty of a felony or misdemeanour, or of an offence against the Act, or who has been guilty of any disgraceful or infamous conduct in a professional respect. The Board is also to have the power to make regulations concerning training, examinations, the fixing of proper titles, and for controlling advertising."

We are glad to see that "the proposed Bill says nothing in the Act shall operate to prevent the practice of optometry by a registered medical ophthalmic specialist."

It is hardly necessary for us to point out that such a Bill, if passed as here set out, would be most detrimental to the public 
welfare for reasons which have already been given both in the report of the Departmental Committee on the "Prevention and Causes of Blindness," and the report of the Council of British Ophthalmologists on "Sight-testing Opticians." At the same time we fully realize the desirability that opticians should hold some qualification for the making of optical instruments and appliances.

\section{ABSTRACTS}

\section{I.-NEUROLOGY}

(I) Pesme, Paul (Bordeaux).- - Typical clinical characteristics of retrobulbar neuritis associated with ethmoidal and sphenoidal sinusitis. (Caractéres clínicos particulares de la neuritis óptica retrobulbar por etmoidoesfenoiditis.) Arch. de Oftal., Vol. XXV, p. 18, January, 1925.

(1) Remarking on the difficulty of tracing the origin of many cases of retrobulbar neuritis, and on the harm of delay in attacking their primary cause, Pesme, from clinical observations, suggests the following syndrome as typical of a neuritis secondary to inflammation of the ethmoid or sphenoid cells :

(1) An absolute central scotoma, for white and colours, leaving the remainder of the field normal.

(2) Signs of inflammation at the papilla, with redness and oedema, instead of the classical picture of a normal fundus, or simply a pallor of the temporal segment of the disc.

This association of a central absolute scotoma with a papillitis, provides, in the author's opinion, sufficient justification for rhinological exploration.

W. S. Duke-Elder.

(2) Larsson, Sven W. (Stockholm).-Choked disc in nephritis. Acta Ophthal., Vol. I, Fasc. 3, 1924.

(2) Larsson discusses the occurrence of choked disc in nephritis generally and reports eleven cases in which he observed it. All the cases were examined with the Gullstrand ophthalmoscope, and all showed increased intracranial and intrathecal pressure, the latter being found in one case to be as high as $600 \mathrm{~mm}$. fluid pressure. Many of the cases had good visual acuity, and in two it improved slightly after lumbar puncture.

He reviews the literature on the subject of the early diagnosis of choked disc and its distinction from purely albuminuric neuroretinal changes and comes to the conclusion that the occurrence 